Original Article

\title{
Activity of Mikania micrantha leaf extract against subterranian termite and wood decay
}

\author{
Yuliati Indrayani*, Alkhadi \\ Department of Forestry, Tanjungpura University, West Kalimantan, Indonesia
}

\begin{abstract}
Mikania micrantha is a wild weed that thrives in tropical areas, grows rapidly in areas with high humidity and light intensity as well as in fertile soil. Meanwhile, Indonesia's tropical climate is also a suitable habitat for the breeding of termites and wood decay fungi. This study aims to determine the bioactivity of M. micrantha leaf extract against subterranean termite, Coptotermes curvignathus (Holmgren) and wood decaying fungus, Schizopyllum commune and its optimal extract concentration to prevent termite attack and inhibit fungal growth. The extracts were obtained by drying and mashing of $M$. micrantha leaves. The leaf powder was sieved with a 40-60 mesh filter and macerated with methanol for $3 \times 24 \mathrm{~h}$. The maceration results were filtered and the filtrate was concentrated using a rotary evaporator. Furthermore, identification of the secondary metabolites of the extract was carried out by phytochemistry. The bioactivity test included anti-subterranean termite and wood decay fungus using Potatos Dextrose Agar (PDA) medium. The results showed that M. micrantha leaf extract affected sample weight loss, termite mortality rates and the growth of wood decay fungi. Furthermore, the concentration of $M$. micrantha extract was inversely proportional to the sample weight loss and directly proportional to the termite mortality rate. In addition, the concentration of $M$. micrantha leaf extract had a negative correlation with the growth of the decaying fungus of $S$. commune therefore, the concentration of the extract was directly proportional to the growth inhibition of fungus. Meanwhile, the $4 \%$ extract concentration led to the increase in termite mortality rate above $80 \%$ and inhibited fungal growth by $100 \%$. The results suggest that the bio-efficacy data from this study may be used to develop wood protecting systems based on wild weeds which are found in tropical areas.
\end{abstract}

Keywords:Termiticide, fungicide, M. micrantha, Schizopyllum commune, Coptotermes curvignathus

Received: 13 November 2020 Revised: 13 January 2021 Accepted: 13 January 2021

\section{Introduction}

Tropical countries have high temperatures and humidity throughout the year and are very favorable for the growth of various kinds of wild weeds such as Mikania micrantha, which grows rapidly, produces vines and disturbs other plants. It has been reported to reduce the production of several plantation crops such as oil palm, rubber, coconut, tea orange, cassava, pineapple, banana, teak, acacia, eucalyptus and albasia (Sankaran, 2008). Due to its wide spread in Indonesia, it has the potential of been exploited.

Apart from $M$. micrantha, Indonesia's tropical climate is also a suitable habitat for termites and wood decay fungi to breed. Coptotermes curvignathus is a subterranean termite that causes economic losses, because it attacks buildings even multi-storey buildings and have also been found to attack oil palm trees in some cases. Controlling this termite is very tasking due to the difficulty in locating its nest. Meanwhile, the wood decay fungi widely found in Indonesia are the Schizopyllum commune Fries species, which are quite malignant and able attack more than 25 species of wood (Maryam, 2011). Therefore the attack caused by these wood-destroying pests needs serious attention. The use of synthetic pesticides to control termites and wood decay fungi have been in existence. However, it has a negative impact, such as polluting the environment which is dangerous to humans and non-target animals.

* Corresponding Author:

Yuliati Indrayani

Faculty of Forestry, Tanjungpura University, Jl. Imam Bonjol, Pontianak 78124, West Kalimantan, Indonesia

Phone:+62-561-764153 Fax:+62-561-764153

e-mail: mandaupermai@yahoo.com
Therefore, natural pesticide development has been carried out to tackle this situation. Furthermore, several studies have explored various natural ingredients to be used as natural pesticides. They include the extract of divine crown stem used against dry wood termites (Lukmandaru and Gazidy, 2016), Euphorbia tirucalli leaf extract is used for larvae-killer for cabbage leaf caterpillars (Toana and Nasir, 2010), Papaya leaf extract and kumis kucing were reported to be used against dry wood termites (Aziz et al., 2018) and Leaf extract of Avicennia marina VIERH to inhibit wood decaying fungi

The widespread of weeds in Indonesia makes these plants potentially used as vegetable pesticides with the advantage of being organic, non-toxic, easy to obtain and cheap. Furthermore, the secondary metabolite mechanism of weeds is different from the synthetic pesticide. Several studies have reported the utilization of weed as a vegetable pesticide, which includes Ageratum conyzoides leaf extract (Isda et al, 2013, Kartika et al., 2016, Wardhiany et al., 2014), Calopogonium mucunoides (Sihombing et al., 2012), Chromolaena odorata (Thamrin et al., 2007, Fitriana et al., 2012, Huzni et al., 2015), Cyperus rotundus and Imperata cylindrical (Arie et al., 2015).

The utilization of $M$. micrantha weed has been reported to be used in the health sector for wound medicine (Fernandes et al., 2018), antibacterial and phytochemical (Matawali et al., 2016, Nasution et al., 2019), anti-cancer (Rahman et al., 2020) and antioxidants (Dev et al., 2015). Furthermore, its utilization as a vegetable herbicide has been reported by Pebriani et al. (2013). Although, there are many studies on its bioactivity, its role as an inhibitor against subterranean termites and wood decaying fungi has not 
been studied much. In addition, it contains secondary metabolites such as alkaloid compounds, triterpenoids and steroids (Fernandes et al, 2018 Polakit et al., 2017), terpenes and sesquiterpenes (Castro et al., 1986). These compounds are known to be toxic to termites and wood decay fungi therefore, its leaves have the potential to be developed as an anti-termite and anti-wood decay fungus.

This study was initiated to evaluate the bio-activity of M. micrantha leaf extract against termites and fungi and to determine the minimum effective concentration against termite mortality and growth of wood decay fungus. In addition, the effectiveness of its weed extracts against subterranean termites and wood decay fungi will be an important part of basic information for integrated pest management.

\section{Methods}

\section{Producing M. micrantha leaf extracts}

The M. micrantha leaves were first dried with indirect exposure to sunlight, crushed into powder and filtered with a mesh size of 40 and 60 . Afterwards, the extraction process was carried out using either the maceration or soaking method. $200 \mathrm{~g}$ of M. micrantha leaf powder was soaked in $1000 \mathrm{~mL}$ of $96 \%$ methanol for $2 \times 24 \mathrm{~h}$ and re-maceration on a shaker at a speed of $150 \mathrm{rpm}$ for $1 \times 24 \mathrm{~h}$. Furthermore, the extract solution obtained was filtered using filter paper to obtain filtrate I and filtrate II from the first maceration and re-maceration results, respectively. These filtrates were evaporated using a rotary evaporator at a speed and temperature of $60 \mathrm{rpm}$ and $45^{\circ} \mathrm{C}$, respectively until all solvent evaporated and a thick extract was obtained (Hajra et al., 2010). The thick extract was diluted to a concentration of $1 \%, 2 \%, 3 \%, 4 \%, 5 \%$ and $6 \%$, respectively using methanol solvent.

\section{Yield analysis}

Yield analysis was determined according to Rahmah et al. (2018). Leaf and extract of M. micrantha were weighed then calculated by dividing the weight of extract with leaf and multiplied by $100 \%$. Yield is calculated based on equations as follow:

$$
\text { Yield (\%) }=\frac{\text { Extract weight }}{\text { Leaf weight }} \times 100 \%
$$

\section{Moisture content analysis}

Moisture content was calculated according to Rahmah et al. (2018). Empty vessel is oven-dried at $105{ }^{\circ} \mathrm{C}$ and cooled in a desiccators for $15 \mathrm{~min}$. The empty vessel was weighed, two g of extract was added into the empty vessel. The vessel containing extract was oven-dried at $105{ }^{\circ} \mathrm{C}$ for three $\mathrm{h}$ then cooled in desiccators for $15 \mathrm{~min}$. Moisture content is calculated based on equations as follow:

Moisture content $(\%)=\frac{\text { Initial weight }- \text { final weight }}{\text { Extract weight }} \times 100 \%$

\section{Phytochemical Screening}

Phytochemical screening of $M$. micrantha leaf extracts is carried out to determine the secondary metabolites compounds present in the extract qualitatively. Phytochemical identification such as alkaloids compound using Dragendroff's test, Mayer's test, and Wagner's test, steroids/triterpenoids compound using Liebermann Bouchard's test, flavonoids compound using $\mathrm{NaOH} 10 \%, \mathrm{H}_{2} \mathrm{SO}_{4}$, and $\mathrm{Mg}+\mathrm{Cl}$, and tannins, saponins, phenolic, and terpenoids compounds as well.

\section{Termite bioassay}

Termite testing was carried out with the No Choice Test method, developed by Ohmura et al., (2000) with modifications. WhatmanTM No. filter paper. 1 Paint No. 1001-055 $55 \mathrm{~mm}$ diameter was used as test sample. The filter paper was cut into a diameter of $30 \mathrm{~mm}$, immersed in the extract solution according to the respective concentration for $1 \mathrm{~h}$ and air-dried for $24 \mathrm{~h}$ before testing. The test was carried out using a plastic cup measuring 50 $\mathrm{mm}$ in diameter and $60 \mathrm{~mm}$ in height. Each cup was filled with sand, size of 30 mesh and held by $10 \mathrm{~g}$ of 50 mesh which has previously been sterilized using an autoclave for $30 \mathrm{~min}$ at a temperature of $120^{\circ} \mathrm{C}$ and a pressure of $1 \mathrm{~atm}$. Furthermore, the sand was moistened with $2 \mathrm{~mL}$ of water to maintain its moisture and a plastic gauze measuring $40 \mathrm{~mm}$ in diameter was placed on the sand to prevent the test sample from coming in direct contact with it (Fig. 1). One filter paper was put in a plastic cup for each concentration and 55 subterranean termites with a ratio of 50 workers to and 5 soldiers' caste termites were added. The study units were stored in a dark room at $\pm 26.9{ }^{\circ} \mathrm{C}-28.3{ }^{\circ} \mathrm{C}$ and $\pm 70 \%-82 \%$ humidity for 21 days. The study was conducted in 5 repetitions. The parameters observed include weight loss of filter paper and the mortality of termites. The weight loss of filter paper was obtained by calculating the percentage of weight loss before and after testing with the following formula:

Weight Loss $=\frac{\left(\mathrm{W}_{1}-\mathrm{W}_{2}\right)}{\mathrm{W}_{1}} \times 100 \%$

Where;

$\mathrm{W}_{1}=$ Filter paper weight before testing $(\mathrm{g})$

$\mathrm{W}_{2}=$ Filter paper weight after testing $(\mathrm{g})$

Termite mortality is the ratio between the number of termites before and after testing expressed in percent. The formula for calculating termite mortality is as follows:

Termite mortality $=\frac{\mathrm{N}}{\mathrm{N}_{1}} \times 100 \%$

Where;

$\mathrm{N}_{1}=$ The number of termites that died in the $\mathrm{i}^{\text {th }}$ test sample (head) $\mathrm{N}_{2}=$ Number of early termites feed (head)

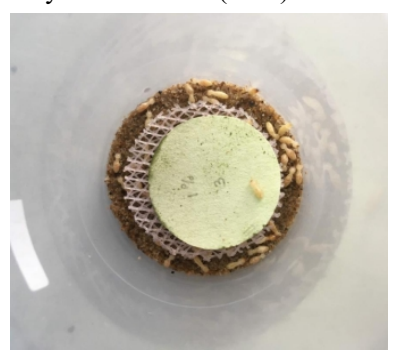

Figure 1. No-choice test method for termite testing 


\section{Fungal bioassay}

The testing of fungal activity of the extracts produced was carried out by measuring mycelium growth in petri dishes (Khan and Zhihui, 2010), we used the wooddecay $S$. commune. M. micrantha leaf extract with each concentration was added to a PDA (Potato Dextrose Agar) solution until it reached $10 \mathrm{~mL}$ and poured into a Petri dish (Fig. 2). The seven-day-old S. commune isolate with a diameter of $5 \mathrm{~mm}$ was planted in the middle of a Petri dish and incubated for seven days at room temperature. The fungal mycelia growth was evaluated at the end of the incubation period and the diameter of the growing fungal colonies were measured using digital callipers. Meanwhile, the calculation of the inhibition percentage was carried out by measuring the colony on the $7^{\text {th }}$ day after inoculation with the following formula (Khan and Zhihui, 2010):

$$
\begin{array}{ll}
\text { AFA }= & \text { GC - GT } \\
\text { Where; } & \text { GC - A } \\
\text { AFA } & =\text { Percentage of inhibition / anti-fungal activity }(\%) \\
\text { GC } & =\text { Diameter of control fungal colony }(\mathrm{mm}) \\
\text { GT } & =\text { Diameter of fungal colonies in media plus extract }(\mathrm{mm}) \\
\text { A } & =\text { Size of the initial incubation mycelium }(\mathrm{mm})
\end{array}
$$

Furthermore, based on the AFA value, the activity of each concentration was classified into activity category levels (Tab. 1). The AFA classification refers to the Mori et al., (1997) which is commonly used in testing wood decay.

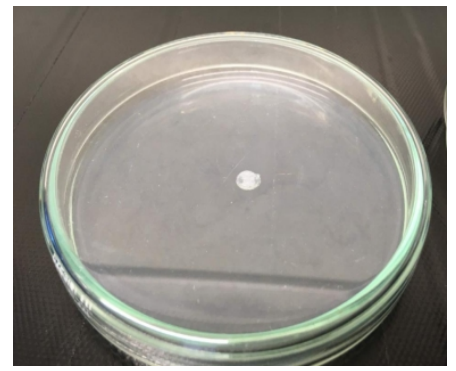

Figure 2. PDA media for wood-decay testing

Table 1. Classification of antifungal activity (AFA)

\begin{tabular}{l|l}
\hline Anti-fungal activity (AFA) & Activity level \\
\hline $\mathrm{AFA} \geq 75 \%$ & Very strong $(++++)$ \\
$75 \% \leq \mathrm{AFA}<50 \%$ & Strong $(+++)$ \\
$50 \% \leq \mathrm{AFA}<25 \%$ & Medium $(++)$ \\
$25 \% \leq \mathrm{AFA}<0$ & Weak $(+)$ \\
0 & Not active $(-)$ \\
\hline
\end{tabular}

\section{Statistical analyses}

The analysis of variance (ANOVA) test was used as a statistical tool. Further analysis to compare between concentration levels uses Tukey's test according to Gaspersz (1991).

\section{Results}

Yield

The extraction process of $M$. micrantha leaves produced an extract yield of $24.35 \%$ with an average moisture content of $9.4 \%$.

\section{Phytochemical screening}

Phytochemical screening is carried out to ensure the presence of secondary metabolites such as alkaloids, flavonoids, phenolics and other compounds potentially inhibit the growth of the wood decay $S$. commune as an anti-termite. This screening was carried out qualitatively to analyze the presence of compounds such as alkaloids, flavonoids, tannins, terpenoids, phenolics, anthraquinones and saponins. Based on the results obtained, it was known that $M$. micrantha leaf extracts were positive for alkaloids, flavonoids, steroids, tannins and phenolic compounds. However, saponins and terpenoids were not found in the extract. The results of the phytochemical screening are presented in Table 2.

Table 2. Phytochemical screening Results of $M$. micrantha leaf extract

\begin{tabular}{l|l|l}
\hline Phytochemical Test & Reactor & Conclusion \\
\hline Alkaloids & Mayer & $(-)$ \\
& Wagner & $(-)$ \\
& Dragendroff & $(+++)$ \\
Flavonoids & NaOH 10\% & $(-)$ \\
& H2SO4 & $(+)$ \\
Mg + HCl & $(-)$ \\
Saponins & Air + HCl & $(-)$ \\
Terpenoids & Liebermann-burchard & $(-)$ \\
Steroids & Liebermann-burchard & $(+)$ \\
Tannins & FeCl3 1\% & $(+)$ \\
Phenolic & FeCl3 1\% & $(+)$ \\
\hline Description: & $(+)$ does not contain \\
& $(+)$ low levels \\
& $(+++)$ high levels
\end{tabular}

\section{Termite bioassay \\ Weight loss}

Termite testing showed that the concentration of $M$. micrantha leaf extract influenced the weight loss of the filter paper after three weeks of feeding on the subterranean termite C. curvignathus (Fig. 3). The test results showed that the concentration of $M$. micrantha leaf extract was inversely proportional to the filter paper weight loss and vice versa. The highest weight loss of filter paper by $80.85 \%$ was discovered in the control, which was the filter paper without the M. micrantha leaf extract. Meanwhile, the lowest weight loss of filter paper was discovered in $6 \% \mathrm{M}$. micrantha leaf extract, which was $11.68 \%$.

Although there was a decrease in filter paper weight loss with the addition of the $M$. micrantha leaf extract, Figure 3 also shows that the concentration of $2 \% \mathrm{M}$. micrantha leaf extract was not significantly different from $3 \%$ and $4 \%$, but was different $5 \%$ and $6 \%$. (Tukey`s test:P $<0.01$ ). Meanwhile, the $3 \%$ concentration 
was not significantly different from the $4 \%$ and $5 \%$, but was different from the $6 \%$ concentration (Tukey's test: $\mathrm{P}$ $<0.01)$. Furthermore, the concentration of $4 \% M$. micrantha leaf extract was not significantly different from the $5 \%$ and $6 \%$ and the $5 \%$ concentration was not different from $6 \%$ (Tukey's test: $\mathrm{P}<0.01$ ).

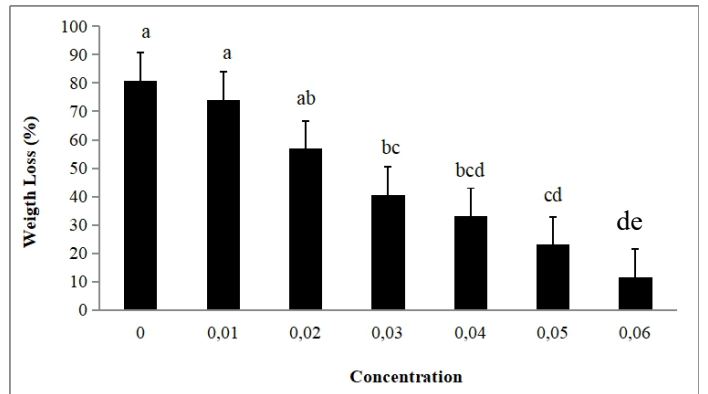

Figure 3. Weight loss of filter paper at various concentrations of $M$. micrantha leaf extract

\section{Termite mortality}

Increasing the concentration of the extract provided better properties to the parameters of weight loss and termites mortality. The effect of $M$. Micrantha leaf extract on termite mortality is presented in Figure 4. $M$. micrantha leaf extract at all concentrations were significantly different from the control (without extract). The concentration of $1 \%$ was not significantly different from $2 \%$ but was different from other concentrations. Meanwhile, the concentration of $4 \%$ was not different from $5 \%$, which was not different from $6 \%$ (Tukey's test: $\mathrm{P}<0.01)$.

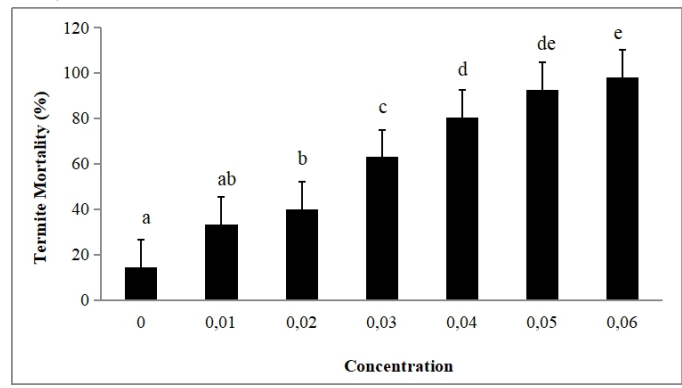

Figure 4. Termite mortality at various concentrations of $M$. micrantha leaf extract

\section{Fungal bioassay}

Anti-fungal activity (AFA)

M. micrantha leaf extract has inhibitory power against the growth of S.commune wood decay fungus. The anti-fungal activity value of $M$. micrantha leaf extract ranged from $78.36 \%$ at a concentration of $1 \%$ to $100 \%$ to a concentration of $4 \%, 5 \%$ and $6 \%$ (Tab. 3). At concentrations of $4 \%, 5 \%$ and $6 \%$ there was no growth in the fungus diameter (Tab. 3). Figure 5 shows that there is no significant difference between the concentrations of $4 \%, 5 \%$ and $6 \%$ (Tukey's test: $\mathrm{P}<0.01$ ), indicating that at a concentration of $4 \%$, it inhibits the growth of wood decay fungus by $100 \%$.

\section{Inhibition of fungal growth}

Measurement of the fungus diameter was carried out on the seventh day because the fungi on the control media were full (Fig. 6). There was no visible growth of fungi at all concentrations on the first and second days of the incubation period. On the third day of incubation, fungal growth was seen on the control media. Meanwhile, on the fourth day of incubation period, fungal growth began to appear on media with $1 \%, 2 \%$ and $3 \%$ concentrations of M. micrantha leaf extract (Fig. 7). Fungal growth did not occur on media with the addition of $M$. micrantha leaf extract at a concentration of $4 \%$, $5 \%$ and $6 \%$ during the incubation period (Fig. 7).

Table 3. Average anti-decay fungal activity of S.commune (AFA) on $M$. micrantha leaf extract at various concentration levels

\begin{tabular}{c|c|c}
\hline Concentration (\%) & AFA mean (\%) & Activity level \\
\hline 0 & 0 & Not active $(-)$ \\
1 & 78.36 & Very strong $(++++)$ \\
2 & 91.70 & Very strong $(++++)$ \\
3 & 94.37 & Very strong $(++++)$ \\
4 & 100 & Very strong $(++++)$ \\
5 & 100 & Very strong $(++++)$ \\
6 & 100 & Very strong $(++++)$ \\
\hline
\end{tabular}

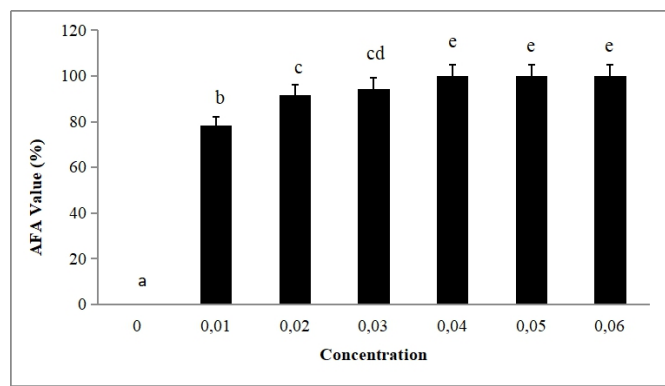

Figure 5. AFA value of $M$. micrantha leaf extract at various concentrations

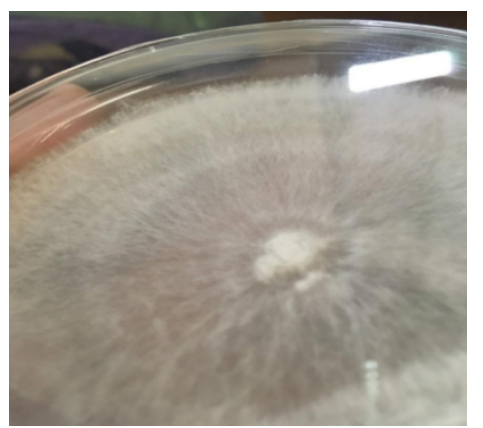

Figure 6. Fungal growth on the controlled media

Figure 6 shows that at the end of the incubation period, the fungi growth on the controlled media was 90 $\mathrm{mm}$, while on the media with a concentration of $1 \%, 2 \%$ and $3 \%$, were $19.99 \mathrm{~mm}, 12.05 \mathrm{~mm}$ and $9.79 \mathrm{~mm}$, respectively. Conversely, no fungal growth was seen at concentrations of $4 \%, 5 \%$ and $6 \%$ (Fig. 7 ).

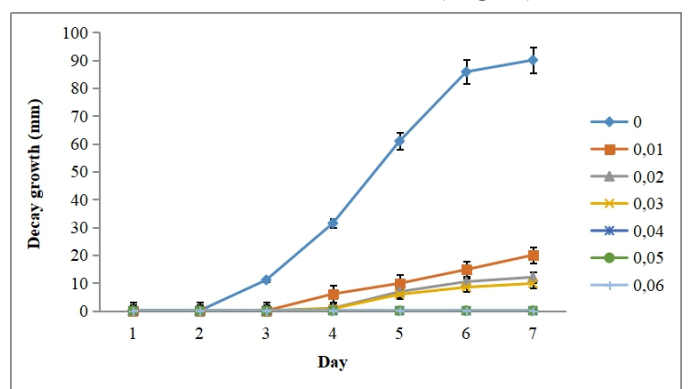

Figure 7. Growth of S.commune wood decay fungus after 7 days of incubation at various concentrations 


\section{Discussion}

\section{Extract content/yield}

The methanol extract content of $M$. micrantha leaves in this study $(24.35 \%)$ was higher than the ethanol extract content of $M$. micrantha by $9.37 \%$ (Perawati et al., 2018), and 3.8\% (Tari et al., 2016). The high level of $M$. micrantha leaf extract in this study was thought to be due to the difference in the solvent used, which the greatly affected the yield of the extract produced. This is understandable since methanol solvents have a Polarity Index (PI) of 6.6, while ethanol solvents have PI of 5.2 (Abarca-Vargas et al., 2016). Fengel and Wegener (1995) clearly stated that the extraction method was a factor that caused variations in the content and composition of extractive substances. The methanol extract content of $M$. micrantha leaves was higher than the extract of other raw materials using the same solvent as lotus weevil with an extract content of $6.62 \%$ (Puspitasari et al., 2013) and Citrus nobilis lime leaves of $19.143 \%$. (Nabu et al., 2015). This is assumed that the bioactive compounds contained in $M$. micrantha leaf are more than lotus weevil and citrus nobilis lime leaves. This results in line with Nurhayati et al. (2009) who states that a high extract content indicating higher in bioactive compounds.

\section{Termite bioassay \\ Weight loss}

Present study revealed that the concentration of $M$. micrantha leaf extract was inversely proportional to the filter paper weight loss and vice versa. Phytochemical test results of $M$. micrantha leaf extract showed that the extract contained alkaloids, flavonoids, steroids, tannins and phenolic chemical elements, which were responsible for the reluctance of termites to eat filter paper because of their anti-crawly properties. Vikery and Vikery (1981) supported the opinion that triterpenoids and their derivatives, including saponins and steroids in plants functioned as insect poisons. Meanwhile, Supriana and Jasni (2004) argued that tannins functions as an inhibitor of damage due to insect attack because they contain phenols which are toxic to wood-destroying organisms. Harborne (1987) added that the main function of tannins in plants is as a repellent for plant-eating insect.

The results obtained from this study were in line with Aziz et al., (2018) which showed that the lowest weight loss was on filter paper with the highest concentration of cat whiskers extract. The effect of concentration on weight loss has also been reported by Wahyudi et al. (2012), Kartal et al. (2012) and Tascioglu et al. (2012; 2013). The comparison of filter paper at each concentration of $M$. micrantha leaf extract after 21 days testing period can be seen in Figure 8.

\section{Termite mortality}

M. micrantha leaf extract had a positive correlation with termite mortality values, which was directly proportional to the extract concentration (Figure 4). These results were supported by Chieng et al. (2008) using Piper sarmentosum extract. The high mortality of termites at a concentration of $6 \%(98.18 \%)$ was inseparable from the role of the alkaloid, flavonoid, steroid, tannin and phenolic bioactive substances found in $M$. micrantha leaf extracts. Toxic materials were in direct proportion to the concentration.

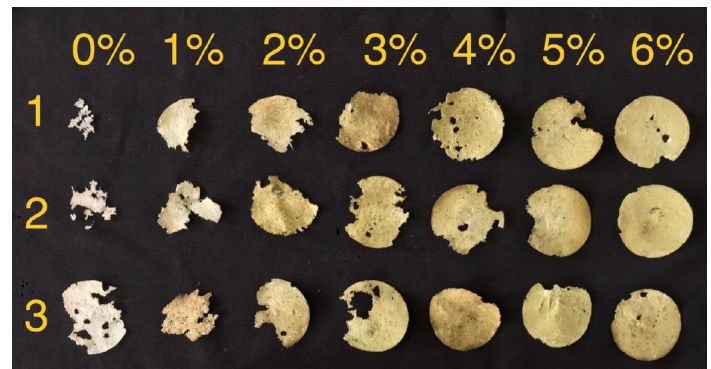

Figure 8. Filter paper condition at various concentrations after 21 days testing period

Furthermore, the high mortality of termites in the extract treatment indicated that it had an anti-termite effect. This was because the chemical compound, especially alkaloids, contents (Tab. 2) affected the eating activity of termites in the form of resistance in eating. Eventually, the termites run out of energy and die.

The weight loss value of filter paper due to $C$. curvignathus termite attack was inversely proportional to the termite mortality value. The low weight loss value of filter paper was followed by the high value of termite mortality. This was due to the reduced number of test termites, therefore, decreasing the physical damage condition or sample weight. M. micrantha leaf extract applied to the filter paper inhibited the termite's feeding rate.

\section{Fungal bioassay \\ Anti-fungal activity (AFA)}

Classification by Mori et al. (1997) showed that $M$. micrantha leaf extract has very strong anti-fungal activity $(++++)$ with AFA values ranging from $78.36 \%$ to $100 \%$ (Table 3 ). Compared with the control, a concentration of $1 \%$ was able to inhibit the growth of $S$. commune wood decay fungus. It was suspected that $M$. micrantha leaves with high extractive content were more resistant to $S$. commune wood decay fungus. This opinion was supported by Lestari and Pari (1990) who stated that tree defence against wood decay fungi was largely dependent on the type and concentration of bioactive compounds in the extractive.

Furthermore, the test results showed that $M$. micrantha leaf extract affected the growth of $S$. commune. The extractive mechanism in inhibiting fungal growth was thought to be due to the presence of chemical compounds that interfered with / stopped the activity of fungal enzymes to break down carbohydrates into materials most easily absorbed for digestion and metabolism of fungi (Syafii et al., 1987; Jayasuriya et al., 2003; Mihara et al., 2005). The case of M. micrantha leaves in this study was that several bioactive compounds in the soluble methanol fraction affected the $S$. commune fungus by inhibiting the growth of their mycelium. Several studies suggest that phenolics and flavonoids inhibit fungal germination (Phongpaichit et al., 2004). 


\section{Inhibition of fungal growth}

The results of this study indicated that an increase in leaf concentration was followed by an increase in inhibition of fungal growth. This proves that $M$. micrantha leaf extract has the potential to be used as a vegetable fungicide. Chemical compounds such as alkaloids, phenolics, flavonoids, steroids and tannins contained in $M$. micrantha leaves were thought to function as inhibitors of the $S$. commune wood decay fungus growth. This opinion was supported by Boulogne et al. (2012) which stated that phenolics, terpenoids and alkaloids are chemical substances with antifungal activity. Harborne (1987) added that tannins are phenolic compounds used as fungicides. The fungi growth on media with various concentrations after the incubation period is presented in Figure 9.

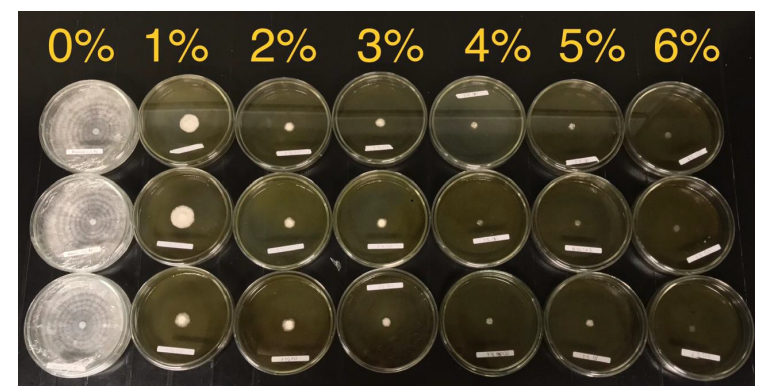

Figure 9. Growth of S.commune wood decay fungus after 7 days of incubation at various concentrations

This study concludes that $M$. micrantha leaf extract has a potential to be used as a natural anti-termite and anti-fungal biocide based on high termite mortalities and fungal inhibition rates. This result suggest that a higher concentration of $M$. micrantha leaf extract could give a better level of protection against termites and wood decay fungi that are less harmful to the environment and humans than recently available ones. Furthermore, the $4 \%$ extract was the optimum concentration for inhibiting the growth of wood decay fungi (very strong category AFA) and caused termite mortality by more than $80 \%$. However, further study is needed to examine $M$. micrantha leaf extract using non-durable wood specimens to develop novel wood protecting biocides.

\section{Acknowledgements}

The author expresses gratitude to Tanjungpura University for funding this study through DIPA Grant and to Maya Viviana for her assistance.

\section{References}

Azis, A., Prayitno, T. A., Lukmandaru, G. \& Listyanto, T. (2018). Antitermite aktivity of papaya and kumis kucing leaves extracts. Journal of Tropical Wood Science and Technology, 16(1), 52-67.

Arie, I. Z., Prasetyo, J., \& Efri. 2015. The effect of imperata, babadotan and teki extracts on anthracnose in Cavendish cultivar banana. Journal of Tropical Agrotech, 3(2), 251-256.

Abarca-Vargas, R., Malacara, C. F. P., \& Petricevich, V. L. (2016). Antioxidant and cytotoxic activities in Bougainvillea $x$ buttiana Holttum and Standl, (var. Rose) extracts. Journal of Antioxidants, 5, 45-56.
Boulogne, I., Petit, P., Lafontaine, H. O., Desfontaines ,L., \& Merciris, G. L. (2012). Insecticidal and antifungal chemicals produced by plants: a review. Environ Chem Lett, 10, 325-347.

Castro, V., Jakupovic, J., \& Bohlmann, F. (1986). Sesquiterpene lactones from Mikania species. Phytochemistry Journal, 25(7), 1750-1752.

Chieng, T. C., Assim, Z. B., \& Fasihuddin. (2008). Toxicity and antitermote activities of the essential oils from Piper sarmentosum. Malaysian Journal of Analytical Sciences, 12(1), 234-239.

Dev, U. K., Hossain, M. T., \& Islam, M. Z. (2015). Phytochemical investigation, antioxidant activity and antihelmintic activity of Mikania micrantha leaves. World Journal of Pharmacentical Research, 4(5), 121-133.

Fernandes, A., Maharani, R., Sunarta, S., \& Rayani. (2018). Chemical characteristics and potential of the leaves of the bulou root plant (Mikania micrantha Kunth) as a traditional wound medicine. Dipterocarp Ecosystem Research Journal, 4(2), 109-116.

Fitriana, Y., Purnomo, \& Hariri, A. M. (2012). Test of the efficacy of Siam weed extract on mortality of pest cocoa pod shoot (Helopeltis spp.) in the Laboratory. J. HPT. Tropical, 12(1), 85-91.

Fengel, D., \& Wegener, G. (1995). Kayu: Kimia, Ultrastruktur, reaksireaksi. In Editor S. Prawirohatmojo (eds). Wood Chemistry, Ultrastructure, Reactions (H. Sastroamijoyo, Trans). Yogyakarta: Gadjah Mada University Press.

Gaspersz, V. 1991. Metode Perancangan Percobaan. CV. Armico. Bandung.

Harborne, J. B. 1987. Phytochemical methods: determining the modern way of analyzing plants. Publisher ITB. Bandung.

Huzni, M., Rahardjo, B. T., \& Hagustarno. 2015. Laboratory test of kirinyuh extract (Chromolaena odorata King \& Robinson) as a vegetable nematicide against Meloidogyne spp. Jurnal HPT, 3(1), 93-101.

Hajra, S., Mehta, A., Pandey, P., John, J., \& Mehta, P. (2010). Antibacterical Property of crude ethanolic extract of Mikania micrantha. Asian Journal of Experimental Biological Sciences, $20(10), 158-160$

Hutabarat, F. V., Diba, F., \& Sisilia, L. (2019). Inhibition of teak bark extract (Tectona grandis Linn) against the growth of wood rot fungus Schizophyllum commune Fries. Sustainable Forest Journal, 7(3), 1078-1089.

Jayasuriya, K. E., Wijesundera, R. L. C., \& Deraniyagala, S. A. (2003). Isolation of antifungal phenolic compounds from petioles of two Hevea brasiliensis (rubber) genotypes and their effect on Phytophthora meadii. Annals of Applied Biology, 142, 63-69.

Polakitan, I. R., Fatimawali, \& Leman, M. A. (2017). Test of the inhibition of the leaf extract of Sembung Rambat (Mikania micrantha) against the growth of Streptococcus mutans. Pharmaceutical Scientific Journal, 6(1), 1-8.

Puspitasari, E., Wardenaar, E., \& Yusro, F. (2013). Activity of methanol extract of lotus flower weevil (Nymphaea lotus L.) for in vitro control of wood decay Schizopyllum commune Fries. Sustainable Forest Journal, 1(3), 252-257.

Perawati, S., Andriani, L., \& Pratiwi P. (2018). Antibacterial activity of ethanol extract of Sembung Rambat (Mikania micrantha Kunth). Chempublish Journal, 3(2), 40-45.

Isda, M. N., Fatonah, S., \& Fitri, R. (2013). The potential of babadotan (Ageratum conyzoides L.) leaf extract on germination and growth of Paspalum conjugatum Berg. Jurnal of Biology, 6(2), $120-125$.

Khan, M. A., \& Zhihui, C. (2010). Influence of garlic root exudates on cyto-morphological alteration of the hyphae of phytophthora capsici, the cause of phytophthora blight in pepper. Journal Botanical, 42(6), 4353-4361.

Kartika, N. I., Salbiah, D., \& Sutikno, A. (2016). Testing of several concentrations of babadotan (Ageratum conyzoides L.) leaf meal extract in controlling green ladybugs (Nezara viridula L.) in long beans (Vigna sinensis L.). JOM. Faperta, 3(1), 1-11.

Kartal, S. N., Terzi, E., Yoshimura, T., Arango, R., Clausen, C. A., \& Green, F. (2012). Preliminary evaluation of storax and its constituents: fungal decay, mold and termite resistance. International Biodeterioration \& Biodegradation, 70, 47-54.

Lukmandaru, G., \& Gazidy, A. A. (2016). Bioactivity and antioxidant activity of the stem extract of the mahkota dewa. Journal of 
Tropical Wood Science and Technology, 14(2), 114-126.

Lestari, S. B., \& Pari, G. (1990). Chemical analysis of several types of Indonesian wood. Journal of Forest Products Research, Center for Forest Products Research and Development, 7(3), 96-100.

Maryam, L. F. (2011). Schizophyllum commune Fr. as a fungus to test the durability of Indonesia's National Standard wood on four wood species: sengon, rubber, tusam, and mangium [Thesis]. Bogor. Bogor Agricultural University.

Mihara, R., Barry, K. M., Mohammed, C. L., \& Mitsunaga, T. (2005). Comparison of antifungal and antioksidant activities of Acacia mangium and Acacia auriculiformis heartwood extracts. Journal of Chemical Ecology, 31(4), 789-804.

Mori, M., Aoyama, M., Doi, S., Kanetoshi, A., \& Hayashi, T. (1997). Antifungal activity of bark extract of deciduous trees. Holz als Roh und Werkstoff, 55, 130-132.

Matawali, A., Chin, L. P., Eng, H., \& Gansau, J. A. (2016). Antibacterial and phytochemical investigations of Mikania micrantha H.B.K. (Asteraceae) from Sabah, Malaysia. Transactions on Science and Technology, 3(2), 244-250.

Novriyanti, E., Santosa, E., Syafii, W., Turjaman, M., \& Irnayuli. R. (2010). Antifungal activity of wood extrat of Aquilaria crassna Pierre ex Lecomte against agarwood-inducing fungi, Fusarium solani. Journal of Forestry research, 7(2), 155-165.

Nabu, Diba, F., \& Dirhamsyah, M. (2015). Anti-termite activity of essential oil from citrus peel Citrus nobilis var.microcarpa against subterranean termites Coptotermes curvignathus Holmgren. Sustainable Forest Journal, 3(1), 133-141.

Nasution, M.Y., Restuati, M., Syahputra, R.A., \& Pulungan, A.S.S. (2019). Antibacterial activity of mandailing traditional plant leaves ethanol extract of Mikania micrantha. Bioscience Research, 16(1), 793-797.

Nurhayati, T., Aryanti, D., \& Nurjanah. (2009). Preliminary study on the potential of sponge as antioxidants. National Oceanic Journal, 2(2), 43-51.

Ohmura, W., Doi, S., Aoyama, M., Ohara, S. (2000). Antifeedant Activity of Flavonoids and Related Compounds Against The Subterranean Termite Coptotermes formosanus Shiraki. J. Wood Sci, 46, 149-153.

Pebriani, Linda, R., \& Mukarlina. (2013). The potential of the leaf extract of sembung rambat (Mikania micrantha H.B.K) as a bioherbicide against Maman Ungu (Cleome rutidosperm D.C) weeds and Bahia grass (Paspalum notatum Flugge). Journal of Protobiont, 2(2), 32-38.

Phongpaichit, S., Pujenjob, N., Rukachaisirikul, V., \& Ongsakul, M. (2004). Antifungal activity from leaf extracts of Cassia alata, L., Cassia fistula L. and Cassia tora L. Journal of Science and Technology, 26(5), 741-748.

Rahman, M. M., Kabir, M. M., Noma, M. A. A., Islam, M. R., Dash, B. K., Akhter, S., Uddin, M. J., \& Rahman, A. (2020). Mikania cordata leaves extract promotes activity against pathogenic bacteria and anticancer activity in EAC cell-bearing swiss albino mice. Journal of Applied Phammaceutical Science, 10(2), 112-122.

Rahmah, N. L., Dewanti, B. S. D., Azizah, F. (2018). Combination of kinetic maceration-digestion in the extraction of areca seeds (Areca catechu L.). Journal Advances in Food Sciencem, Sustainable Agriculture and Agroindustrial engineering, $1(2): 27-33$.

Sankaran, K. V. (2008). Mikania micrantha H.B.K invasive pest fact sheet. APFSIN.

Sihombing, A., Fatonah, S., \& Silviana, F. (2012). Effects of allelopathy Calopogonium mucunoides Desv. on the germination and growth of Asystasia gangetica (L.) T. Anderson sapling. Biospecies, 5(2), 5-11.

Syafii, W., Samijima, M., \& Yoshimoto, T. (1987). The role of extractives in decay resistance of ulin wood (Eusideroxylon zwageri T. et B.). Bulletin of Tokyo University Forest, 77, 1-8.

Salam, D. M., Mukarlina, \& Diba, F. (2014). Pengendalian rayap tanah Coptotermes curvignathus Holmgren menggunakan ekstrak daun gulma Sembung Rambat (Mikania micrantha Kunth). Protobiont, 3(2), 87-92.

Setiawan, A., Diba, F., \& Wardenaar, E. (2019). Anti-fungal activity test of api-api leaf extract (Avicennia marina VIERH) to inhibit the growth of the fungus Schizophyllum commune FRIES. Sustainable Forest Journal, 7(1), 517-524.
Toana, M. H., \& Nasir, B. (2010). Study of bioactivity and isolation of plant bioactive compounds Euphorbia tirucalli L. (Euphorbiaceae) as an alternative botanical insecticide. Journal of Agroland, 17(1), 47-55.

Tascioglu, C., Yalcin, M., Troya, T., \& Sivrikaya, H. (2012) Termiticidal properties of some wood and bark extracts used as wood preservatives. BioResources, 7(3), 2960-2969.

Tascioglu, C., Yalcin, M, Sen, S., \& Akcay, C. (2013). Antifungal properties of some plant extracts used as wood preservatives. International Biodeterioration \& Biodegradation, 85, 23-28.

Thamrin, M., Asikin, S., Mukhlis, \& Budiman, A. (2007). Potential of swampland flora extract as a natural pesticide. Swamp Land Agricultural Research Center, 35-54.

Tari, M., Lidia, \& Lely, N. (2016). Antibacterial activity test on some of the leaves fraction of sembung rambat (Mikania micrantha Kunth) against skin disease bacteria. Pharmaceutical Scientific Journal, I(2), 49-54.

Vickery, M. L., Vickery, B. (1981). Secondary Plant Metabolism. The Macmillan Press, London.

Wardhiany, C. K., Sritamin, M., \& Yuliadhi, K. A. (2014). Test studies of extracts of several types of weeds in suppressing root purulent nematodes Meloidogyne spp. in tomato (Licopersicum esculentum Mill). E Journal of Tropical Agroecotechnology, 3(1), 32-40.

Wahyudi, Ohtani, Y., \& Ichiura, H. (2012). Berberine in the medicinal plant of tali kuning (Tinospora dissitiflora Diels). Wood Res J., 2(2), 100-104. 